\title{
STRATEGI PT. CIRACASINDO PERDANA DALAM PERSAINGAN USAHA DENGAN METODE QUANTITATIVE STRATEGIC PLANNING MATRIX DAN SWOT
}

\author{
Jeremy Jonathan \\ Program Studi Magister Manajemen Universitas Tarumanegara \\ jonathanjeremy@rocketmail.com
}

\begin{abstract}
Abstrak : Penelitian ini bertujuan untuk merumuskan dan mengetahui strategi yang paling sesuai dari PT. Ciracasindo Perdana dalam menghadapi persaingan usaha food and beverages yang ketat dengan metode Quantitative Strategic Planning Matrix dan analisa SWOT. Jenis penelitian yang digunakan adalah jenis penelitian kualitatif yang bersifat deskriptif. Data-data yang diperoleh diambil dengan teknik wawancara langsung kepada tiga narasumber dari perusahaan. Selain itu juga menggunakan observasi langsung di lapangan dan analisa kepustakaan seperti buku, company profile, dan laporan keuangan perusahaan. Dari sisi eksternal perusahaan, diketahui faktor yang paling berpengaruh pada perkembangan perusahaan yaitu sektor dari pangsa perusahaan cukup luas dan dapat dijadikan sebagai peluang, sementara faktor eksternal yang paling berpengaruh adalah banyaknya kompetitor pada bidang bisnis ini yang menjadi ancaman perusahaan. Sedangkan di sisi internal, perusahaan menonjolkan kualitas produk dan peningkatan pelayanan kepada pelanggan sebagai kekuatan utama perusahaan. Sementara yang dijadikan sebagai kelemahan perusahaan yang harus diperbaiki adalah kurangnya diferensiasi produk dan tidak agresifnya pengenalan produk di pasar. Perusahaan sendiri sedang berada pada posisi pasar yang sedang bertumbuh dan agresif sehingga meghasilkan 2 opsi strategi yang dapat diambil perusahaan ke depan yaitu perluasan pasar baru dengan dari sektor pasar utama yang ada dan juga perluasan produk baru dari produk unggulan yang selama ini dijual di pasaran. Dengan metode QSPM (Quantitative Strategic Planning Matrix) dan kemudian didapat kembali beberapa kesimpulan yang berupa analisa SWOT (Strength Weakness Opportunity Threat) perusahaan, maka strategi yang paling cocok pada perusahaan dengan kondisi pasar yang ada yaitu perlunya perluasan produk baru.
\end{abstract}

Kata Kunci : Strategi bisnis, kualitatif, QSPM, SWOT

\section{PENDAHULUAN}

Beberapa tahun belakangan ini, industri makanan dan minuman merupakan salah satu industri yang paling stabil perkembangannya atau bahkan terus menanjak dibandingkan oleh sektor bisnis lain di Indonesia yang kerap mengalami pasang surut. Di Indonesia sendiri, menurut GAPMMI (Gabungan Pengusaha Makanan dan Minuman Seluruh Indonesia) dan data dari BPS (Badan Pusat Statistik), sampai dengan akhir 2017, Industri makanan dan minuman terhitung memiliki pertumbuhan tertinggi diantara bisnis lainnya yaitu sekitar 9,23\%. Dengan tren bisnis yang stabil dan cenderung naik, membuat bisnis retail makanan dan minuman menjadi salah satu bisnis yang banyak dilirik dan memiliki persaingan yang ketat. Di sektor minuman atau Beverage, pasar ritel Indonesia menjadi pasar yang sangat menggiurkan untuk para pebisnis. Minuman seperti sari buah atau Jus buah menjadi salah satu produk pilihan masyarakat terlebih dengan sifatnya yang praktis dan sangat mudah untuk dikonsumsi.

Dikutip dari halaman daftar keanggotaan GAPMMI, sampai dengan tahun 2015, jumlah perusahaan makanan dan minuman yang terdaftar di Indonesia sudah mencapai angka 400 lebih perusahaan yang terdaftar secara resmi. Hal tersebut mengindikasikan tingginya tingkat persaingan pada sektor bisnis ini di Indonesia. Salah satu perusahaan makanan dan minuman tersebut adalah PT Ciracasindo Perdana yang merupakan produsen dan distributor minuman dengan produk utama yaitu sari buah untuk keperluan industri dan juga ritel. Industri yang menjadi pasar utama yaitu seperti sektor manufaktur untuk makanan dan minuman dan sektor 
pariwisata. Persaingan usaha pada bidang sejenis dipenuhi oleh perusahaan lokal maupun asing karena pasar yang cukup luas dan menarik di Indonesia. Persaingan semakin agresif belakangan ini karena kebutuhan yang semakin banyak. Maka dari itu untuk bersaing pada sektor bisnis makanan dan minuman ini memerlukan strategi-startegi yang baik agar dapat menjadi perusahaan yang unggul atau setidaknya dapat bertahan pada tingkat persaingan yang semakin ketat.

\section{TUJUAN PENELITIAN}

Tujuan dilakukannya penelitian ini adalah untuk merumuskan strategi dari PT Ciracasindo Perdana dalam menghadapi persaingan yang ketat dengan menggunakan metode Quantitative Strategic Planning Matrix (QSPM) dan analisa SWOT.

\section{TINJAUAN PUSTAKA}

Menurut Fred \& David (2015), Manajemen stratejik adalah seni dan sains dalam memformulasi, mengimplementasi, dan mengevaluasi keputusan lintas fungsional yang membuat organisasi dapat memperoleh tujuannya. Sedangkan menurut Philip Kotler \& Keller (2008), perencanaan pemasaran strategis atau strategic marketing plan adalah sebuah konsep yang menjelaskan pasar sasaran dan proposisi nilai yang akan ditawarkan oleh perusahaan berdasarkan pada analisis peluang terbaik.

Pada tehnik formulasi strategi perusahaan terdapat 3 (tiga) kerangka kerja yang dapat diterapkan oleh semua bidang bisnis atau juga disebut multi bisnis. Menurut Fred \& David (2015), semua alat yang disajikan di dalam kerangka kerja ini dapat diaplikasikan untuk semua tipe dan ukuran organisasi yang membantu dalam penyusunan strategi, mengidentifikasi, mengevaluasi, dan memilih dan memutuskan strategi perushaan yang paling cocok diterapkan. 3 kerangka kerja tersebut antara lain: (1) Tahap 1 yang disebut juga tahap input atau input stage, berisikan semua inputan atau masukan dasar yang dibutuhkan untuk membuat formulasi strategi pada tahap tahap selanjutnya. Pada tahap 1 tersebut berisikan matriks EFE (External Factor Evaluation), matriks IFE (Internal Factor Evaluation) dan juga matriks CPM (Competitive Profile Matrix). (2) Tahap 2 atau disebut juga tahap pencocokan yaitu tahap dimana faktor-faktor yang dimasukkan pada tahap input atau tahap 1 kemudian dicocokkan dengan kesempatan dan ancaman dari luar perusahaan (eksternal) dan juga kelemahan dan kekuatan dari dalam perusahaan (Internal). Pencocokan tersebut dinilai sangat efektif dalam pemilihan atau penentuan strategi - strategi bisnis ke depannya karena pada tahap ini kita dapat melihat sisi internal dan eksternal perusahaan lebih dalam lagi. Pada tahap ini juga faktor faktor yang ada dalam analisis SWOT (Strengths, Weaknesses, Opportunities, \& threats) sangat membantu dalam analisa strategi perusahaan, karena hubungan semua faktor tersebut sangat berkaitan erat dengan faktor yang ada di tahap input sehingga dapat menghasilkan sebuah alternatif-alternatif strategi yang baru. Dalam tahap ini terdapat 5 kerangka kerja, yaitu, Matriks SWOT, Matriks SPACE, Matriks BCG, Matriks, IE, dan Matriks Grand Strategy. (3) Decision stage atau tahap keputusan hanya memiliki satu kerangka kerja final yaitu QSPM (Quantitative Strategic Planning Matrix) yang dapat mengungkapkan daya Tarik relatif dari srategi alternatif dan memberikan dasar penilaian yang objektif dalam meilih strategi tertentu, menurut Fred \& david (2015). Cara kerja dari tahap ini adalah dengan mengevaluasi semua hasil masukkan dari tahap 1 atau tahap input kemudian dicocokan ke dalam SWOT di tahap pencocokan dan yang terakhir ditarik ke dalam matriks $Q S P M$ itu sendiri sehingga dapat mengeluarkan nilai-nilai yang dapat membantu perusahaan dalam pemilihan strategi bisnis yang paling cocok diterapkan di perusahaannya.

\section{METODOLOGI PENELITIAN}

Penelitian ini merupakan peneliatian kualitatif yang bersifat deskriptif. Data-data yang didapatkan diperoleh dari hasil wawancara kepada 3 narasumber dari PT. Ciracasindo Perdana. 
3 orang tersebut adalah Direktur Utama, Direktur, dan Komisaris perusahaan. Wawancara dilakukan dengan daftar pertanyaan yang dibuat oleh peneliti kemudian dipakai untuk wawancara langsung ketiga narasumber. Hasil dari wawancara tersebut kemudian dicocokkan dengan teori yang dipakai sehingga menghasilkan data sesuai topik pembahasan.

\section{HASIL \& KESIMPULAN}

Dengan menggunakan matriks Quantitative Startegic Planning Matrix (QSPM), ditentukan dua alternatif strategi secara garis besar yaitu perluasan pasar yang baru dan perluasan produk yang baru. Setelah dicocokkan dengan IFE (Internal Factors Evaluation) dan EFE (External Factors Evaluation) serta secara subjektif ditentukan daya tarik dari setiap faktor dengan strategi perusahaan alternatif, maka dihasilkan 2 bobot nilai untuk masingmasing strategi alternatif.

Pada PT. Ciracasindo Perdana tersebut diketahui atau ditentukan penerapan strategi yang paling baik adalah dengan cara pengembangan dan perluasan pasar yang baru yang lebih luas. Strategi alternatif tersebut mendapatkan bobot yang paling tinggi berdasarkan penilaian subjektif. Dengan kondisi ekonomi yang sedang bertumbuh pada sektor usahanya serta tingkat kompetisi yang ketat dan kompetitif, maka jalan strategi yang paling baik adalah dengan pengembangan pasar yang lebih luas dan pengenalan produk-produk diluar pasar yang sudah ada dari sekarang ini.

Berdasarkan penelitian dan juga alternatif strategi yang didapat, dapat ditarik beberapa kesimpulan yaitu Persaingan pada bisnis Food and Beverage sendiri di Indonesia merupakan persaingan pasar yang cukup ketat dan kompetitif dilihat dari faktor - faktor pendukung sektor bisnis ini di Indonesia. PT. Ciracasindo Perdana sebagai salah satu perusahaan yang sudah cukup lama ada di sektor bisnis Food and Beverage berada pada posisi kompetisi bisnis yang sangat ketat dan juga pada sektor pertumbuhan bisnis yang baik. Kekuatan utama dari PT. Ciracasindo Perdana terletak pada keunggulan harga dan juga keunggulan kualitas karena perusahaan memiliki kegiatan produksi yang diawasi dan dikelola dengan cukup baik. Kelemahan utama yang dimiliki oleh PT. Ciracasindo Perdana adalah produk yang dimiliki oleh perusahaan sangat terbatas dan terkesan jenuh di masyarakat. Serta ditambah kurangnya pengenalan dan pemasaran produk itu sendiri di masyarakat atau terbilang sangat segmented. Peluang terbesar yang dimiliki oleh perusahaan adalah dengan pasar di Indonesia yang begitu luas serta sekotr usaha yang cenderung stabil membuat PT Ciracasindo perdana berpeluang untuk melebarkan usahanya. Ancaman terbesar perusahaan yaitu kompetisi yang sangat agresif dan ketat di pasar Food and beverages.

Dari alternatif strategi dan juga analisa SWOT perusahaan, disarankan strategi perusahaan dalam menyikapi persaingan bisnis Food and beverage adalah dengan cara perluasan pasar yang lebih agresif lagi dibandingkan dengan pasar yang telah dimasukki perusahaan saat ini.

\section{DAFTAR PUSTAKA}

Blery, Evangelia \& Eugenia, Marketing Olive Oil in Greece, melalui www.emeraldinsight.com BPS, (2017), Pertumbuhan Industri Makanan dan Minuman, Diperoleh dari : https://bisnis.tempo.co/read/1127039/industri-makanan-dan-minuman-tumbuh-867persen-triwulan-ii-2018/full\&view=ok

David R, Fred, (2015), Manajemen Staregik, Jakarta : Salemba Empat

Gabungan Pengusaha Makanan dan Minuman Indonesia, (2017), Pertumbuhan Industri Makanan dan Minuman, Diperoleh dari : https://bisnis.tempo.co/read/1127039/industrimakanan-dan-minuman-tumbuh-867-persen-triwulan-ii-2018/full\&view=ok

Gabungan Pengusaha Makanan dan Minuman Indonesia, (2018), Jumlah Keanggotaan Pengusaha Makanan dan Minuman, Diperoleh dari: http://www.gapmmi.or.id/?pilih=hal\&id=5 
Kotler, Philip \& Keller. 2008. Manajemen Pemasaran, jilid 1. Jakarta : Airlangga

Setyorini, Hani \& Mas'ud Effendi \& Imam Santoso. Analisis Strategi Pemasaran Menggunakan Matriks SWOT dan QSPM. Jurnal Teknologi dan Manajemen Agroindustri, melalui www.industria.ub.ac.id 